\title{
SOME EARLY MAY \\ BIRD OBSERVATIONS \\ IN THE CYPRESS HILLS REGION
}

CHARLES HARPER, 1049 Retallack Street, Regina, Saskatchewan, and ROBERT KREBA, \#4-2805 Parliament Avenue, Regina, Saskatchewan

The authors spent a long weekend (0730 May 6 to 1500 May 8,1977$)$ in the Cypress Hills region of southwestern Saskatchewan (as defined by Godfrey) ${ }^{2}$, resulting in some interesting observations. In 34 hours of actual observation time and 305 miles of travel ( 295 by car and approximately 10 on foot) we observed a total of 93 species, in the more restricted area of the Provincial Park units (West and Centre Blocks) the total was only 72 pecies. Most of the species not within the Provincial Park units were hose found in prairie sloughs, which are almost nonexistent in the Hills proper. Several species were conpicuous by their absence; however, ve did not cover the area in its entire$y$, concentrating our efforts in the Cypress Hills Provincial Park, paricularly the two nature trails in Cenre Block, and Coulee and Adams akes in West Block.

We observed four species which re not listed either by Godfrey ${ }^{2}$ or Morrison ${ }^{3}$, although two of them vere recorded by observers at the 976 Saskatchewan Natural History ociety (SNHS) field trip. ${ }^{4}$ These were:

RROAD-WINGED HAWK. A single dult at Valley of the Beavers Nature rail, Central Block, at 1235 and 1405 n May 6, and again at 1907 on May 8. his was probably one of a pair seen $t$ the same location in $1976 .{ }^{4}$

ELLOW-BELLIED SAPSUCKER. A ngle male at Rainbow Campground, entre Block, on May 7 and 8. A ngle bird was also seen in 1976, Loch even area. ${ }^{4}$

OLDEN-CROWNED KINGLET. A rilliantly crowned male, at Rippling Vaters Nature Trail, Centre Block, lay 6.

MYRTLE" WARBLER. One male seen in mixed deciduous woodland bordering pasturage south of Coulee and Adams Lakes, West Block, May 7. The "Myrtle" Warbler is presently regarded as the eastern equivalent of "Audubon's" Warbler, which replaces it in the Cypress Hills and is a common breeder there; the two are now combined as the Yellow-rumped Warbler. ${ }^{1}$

Some other observations which may be of interest are:

RED-NECKED GREBE. 10 at Coulee Lake and 4 at Adams Lake, West Block area, May 7. Apparently paired birds on territory, they were quite vocal but no courtship display was observed. \section{DOUBLECRESTED CORMORANT.} 35 at Adams Lake (May 7), 4 at Coulee Lake (May 7), and 3 at Loch Leven, Centre Block (May 8).

TRUMPETER SWAN. One adult, standing on lakeshore and in flight, at Adams Lake, West Block, May 7 and a pair calling and flying low towards the southeast, Rainbow Campground in Centre Block, May 8. The bird at Adams Lake had the head and most of the neck stained rusty.

OSPREY. One bird seen soaring at medium height over Valley of the Beavers Nature Trail, Centre Block, May 6.

RUFFED GROUSE. One grey phase male, very tame, in deciduous woodland below Bald Butte, Centre Block, May 6. These birds were introduced into the Cypress Hills in the 1920 's.

FORSTER'S TERN. 4 birds, apparently two pairs, at Adams Lake, West Block, May 7.

SPRAGUE'S PIPIT. Common; one or two heard singing at every stop on the 


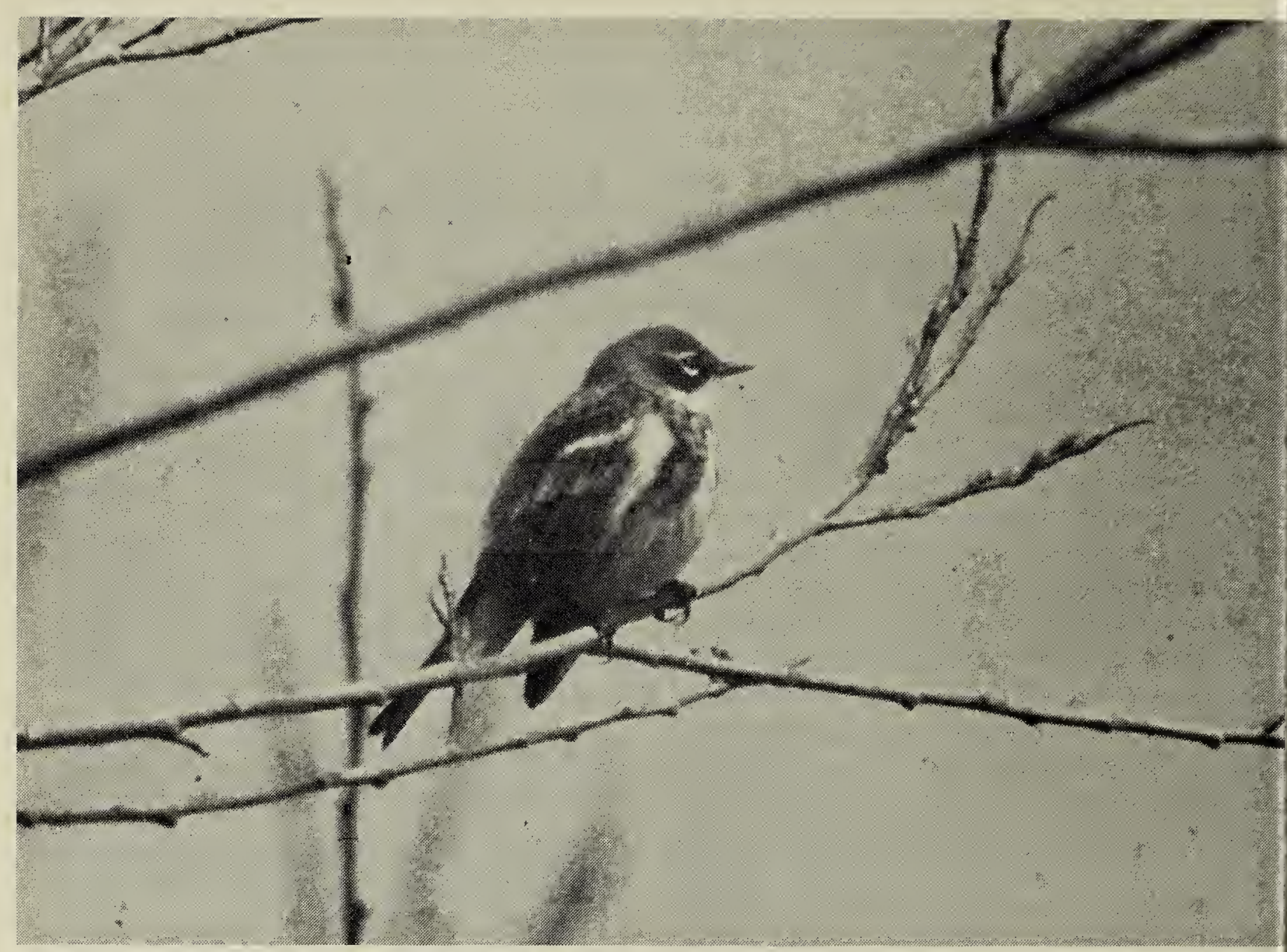

Yellow-rumped (Myrtle) Warbler

F. W. Lahrma

Yellow-bellied Sapsucker

F. W. Lahrma

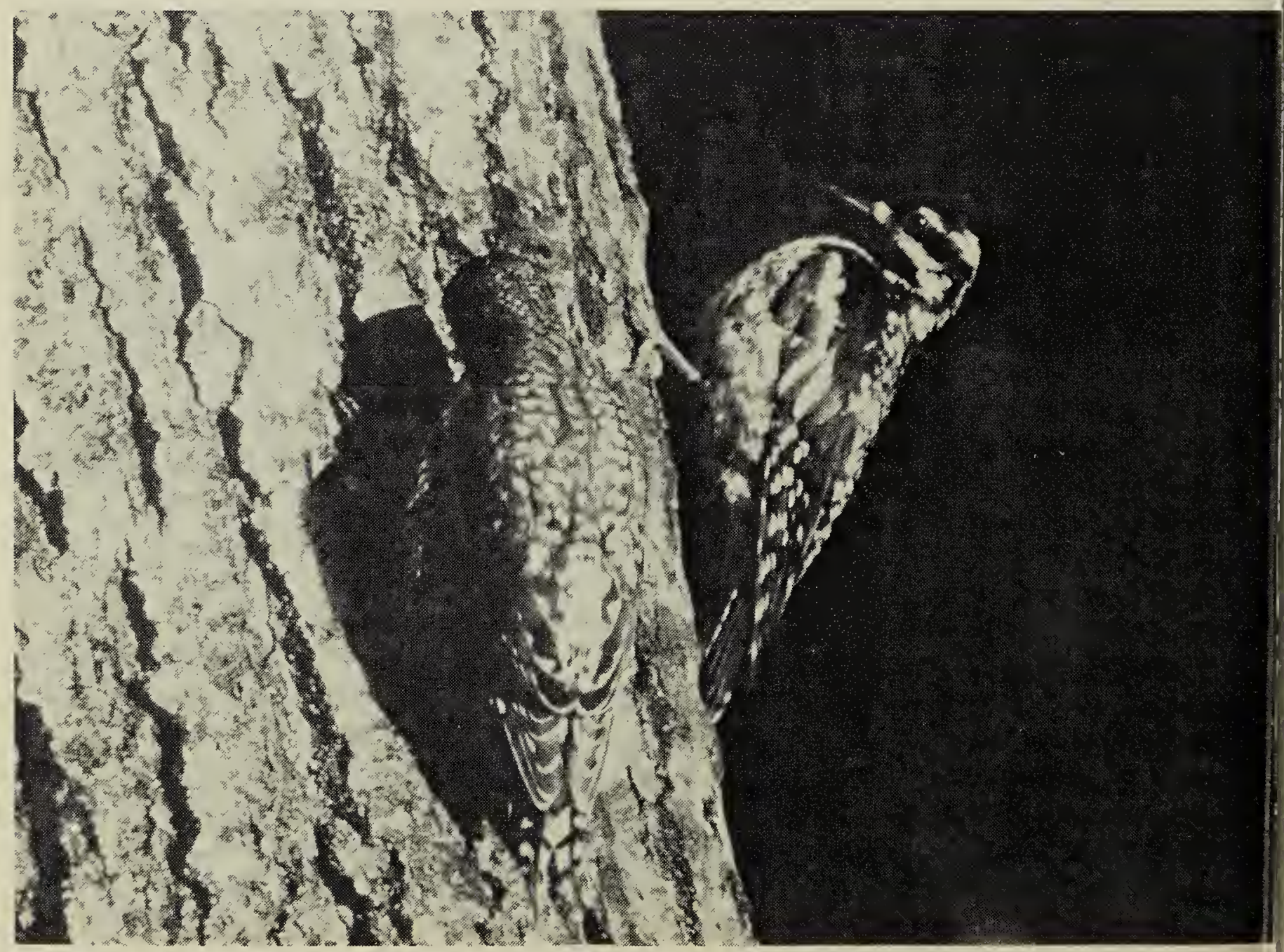


Gap Road and the West Block plateau, May 7.

RED CROSSBILL. A pair and 3 recently fledged young at Rainbow Campground, Centre Block. Young were fully fledged, but awkward fliers; male was observed removing seeds from Lodgepole Pine cones and feeding young birds on the ground several times on May 8.

LARK SPARROW. 2 seen; one in the Centre Block, near the Lodgepole Pine plantation (seen chasing an "Oregon" Junco) May 7, and one seen on upper east slope West Block, May 7. This species not recorded on SNHS trip, June, $1976 .{ }^{4}$

Following is a list of the species seen and positively identified during our trip. As only two observers were involved, we have decided to indicate only numbers of each positively identified species, rather than attempt to indicate relative abundance. Our intention was not to conduct an intenfive survey, and for this reason numbers are admittedly low for many pecies; hundreds of specifically undentified waterfowl, shorebirds, gulls and the like are not included. As mentioned, the area covered is that ised by Godfrey, ${ }^{2}$ which is somewhat more extensive than the area most contemporary naturalists would call he Cypress Hills. Species recorded pnly outside the Centre and West Blocks and the Gap are designated d), following Wedgewood. ${ }^{4}$

4 Red-necked Grebe, 1 Horned Grebe, 83 ared Grebe (d), 4 Western Grebe (d), 2 ied-billed Grebe (d), 1 White Pelican (d), 2 Double-crested Cormorant, 4 Great Blue Heron, 10 Whistling Swan (d), 3 rumpeter Swan, 63 Canada Goose, 49 Mallard, 4 Gadwall, 47 Pintail, 8 Greenvinged Teal, 70 Blue-winged Teal, 44 merican Wigeon, 23 Northern Shoveler, 0 Canvasback, 23 Lesser Scaup, 4 Comhon Merganser, 1 Sharp-shinned Hawk d), 6 Red-tailed Hawk, 1 Broad-winged lawk, 17 Swainson's Hawk, 1 Ferruginous lawk, 7 Marsh Hawk, 1 Osprey, 1 Prairie alcon (d), 1 Ruffed Grouse, 5 Sharptailed jrouse, 31 American Coot, 17 Killdeer, 6 Fommon Snipe, 2 Upland Plover (d), 1 potted Sandpiper, 21 Willet, 3 Lesser ellowlegs (d), 74 Long-billed Dowitcher (d), 3 Semipalmated Sandpiper (d), 18 Marbled Godwit, 8 American Avocet (d), 115 Wilson's Phalarope, 7 California Gull, 6 Ring-billed Gull, 16 Franklin's Gulls, 4 Forster's Tern, 4 Common Tern (d), 7 Rock Dove (d), 10 Mourning Dove, 1 Belted Kingfisher, 3 "Red-shafted" (Common) Flicker, 1 Yellow-bellied Sapsucker, 1 Hairy Woodpecker, 1 Downy Woodpecker (d), 3 Say's Phoebe, 63 Horned Lark, 4 Tree Swallow, 14 Barn Swallow, 25 Black-billed Magpie, 43 Common Crow, 5 Blackcapped Chickadee, 5 Red-breasted Nuthatch, 31 American Robin, 5 Mountain Bluebird, 1 Golden-crowned Kinglet, 7 Ruby-crowned Kinglet, 4 Water Pipit (d), 19 Sprague's Pipit, 2 Loggerhead Shrike (d) 5 Starling, 4 Orange-crowned Warbler, 1 "Myrtle" (Yellow-rumped) Warbler, 5 "Audubon's" (Yellow-rumped) Warbler, 17 House Sparrow (d), 54 Western Meadowlark, 10 Yellow-headed Blackbird (d), 71 Red-winged Blackbird, 67 Brewer's Blackbird, 6 Common Grackle (d) 5 Brown-headed Cowbird, 5 Red Crossbill, 1 Rufous-sided Towhee, 27 Savannah Sparrow, 13 Vesper Sparrow, 2 Lark Sparrow, 18 "Oregon" (Dark-eyed) Junco, 4 Clay-colored Sparrow, 2 White-crowned Sparrow, 2 Song Sparrow, 3 McCown's Longspur, 3 Chestnut-collared Longspur (d).

Eight additional species were added to the total trip list during the drive between Regina and the Cypress Hills area and back:

4 Redhead, 2 Ruddy Duck, 1 American Kestrel, 2 Semipalmated Plover, 2 Golden Plover, 6 Short-billed Dowitcher, 3 Pectoral Sandpiper, 16 Baird's Sandpiper. The Short-billed Dowitchers were sorted out of a flock of approximately 500 Long-billed Dowitchers, just west of Morse, May 6.

'AMERICAN ORNITHOLOGISTS' UNION. 1973. Thirty-second Supplement to the AOU Checklist of North American Birds. Auk 90:411-419.

${ }^{2}$ GODFREY, W. E. 1950. Birds of the Cypress Hills and Flotten Lake regions, Saskatchewan. Bull. 120, Nat. Parks Branch, Nat. Mus. of Canada.

${ }^{3}$ MORRISON, H. 1973. The Cypress Hills A natural history. Popular Series 15, Saskatchewan Mus. Nat. Hist.

${ }^{4}$ WEDGEWOOD, J. A. 1976. Bird notes on the Cypress Hills Summer Meeting. Blue Jay 34:172-175. 